J. Environ. Sci.

Institute of Environmental Studies and Research - Ain Shams University

\title{
DECOLORIZATION OF REMAZOL BLUE AND \\ REMAZOL RED USING ASPERGILLUS NIGER ISOLATED FROM TEXTILE WASTEWATER
}

\author{
Abeer, M. Mohamed ${ }^{(1)}$; Dalia, A. M. Abduo ${ }^{(2)}$; \\ Al-zahraa, A. Karam Al- Dien ${ }^{(2)}$; Elshhat, M. Ramadan ${ }^{(3)}$ \\ and Taha M. Abd Elrazek ${ }^{(4)}$
}

1) Department of Occupational Environment, National Institute of Occupational Safety and Health (NIOSH).2) Department of Microbiology, Faculty of Science, Ain Shams University 3) Department of Microbiology, Faculty of Agriculture, Ain Shams University 4) Department of Basic Sciences Institute of Environmental Studies and Research, Ain Shams University.

\begin{abstract}
Discharge of textile dyes in wastewater of textile factories represents a major environment problem threatening the aquatic life. The decolorization of such harmful chemicals is of paramount importance. In this work, Aspergillus niger, a brown rot fungi, isolated from the effluent samples around the textile industry of El- Baragil, Giza, Egypt was evaluated for its efficiency in decolorization of two textile dyes; Remazole blue and Remazol red. Effluent samples were also analyzed for their physiochemical properties. The optimum conditions for decolorization were found to be 4 days incubation, $30^{\circ} \mathrm{C}$ and $\mathrm{pH} 4$ in Sabouraud liquid medium supplemented with dextrose $(10 \mathrm{~g} / \mathrm{l})$ and ammonium sulfate $(2 \mathrm{~g} / \mathrm{l})$ as a carbon and nitrogen source, respectively. The response of the isolate to the increase in dye concentrations was found to be growth inhibitory. Decolorization extent and facile conditions showed the potential for the A.niger to be used in biological treatment of textile dyes. Keywords: A.niger, Decolorization, Physiochemical, Textile dyes.
\end{abstract}




\section{INTRODUCTION}

Wastewater from textile industry is considered as one of the major sources of pollution due to the great demand for textile products resulting proportional increase in production and application of synthetic dyes (Balapure et al., 2014). Azo dyes represent the most common group of synthetic dyes constituting $60-70 \%$ of more than 10,000 dyes used in textile industry (Ong et al., 2010). It is estimated that about $2 \%$ and $10-15 \%$ of azo dyes are lost during manufacture and dyeing processes, respectively (Pearce et al., 2003). Release of theses dyes into the environment causes an adverse impact on the aquatic ecosystem because that they are considered to be toxic to aquatic biota and are reported to be carcinogenic to humans (Tauber et al., 2008). Although their contribution to organic load may sometimes be not significant, even the presence of low concentrations of dyes would impart an intense color to these wastewaters (Singh et al., 2007). Therefore, effective treatment of azo-dye-containing wastewaters before discharge into the environment should be emphasized. Compared with physical and chemical processes, biological methods are generally considered as better alternatives for treatment of azo-dye-containing wastewaters due to their lower cost, higher efficiency and less secondary pollution (dos Santos et al., 2007). Highly efficient microorganisms are the most important factors for effective biological treatment processes. For a long time, the corresponding researches are mainly focused on bacteria and fungi (de Miranda et al., 2013). Decolorization generally occurs by the adsorption of dyestuffs on bacteria, rather than oxidation in aerobic systems. Some bacteria can biodegrade 
dyestuffs by azoreductase activity. However, the effluent at the end of biotransformation of dyestuffs could be toxic (Chung and Stevens, 1993). These problems limit large-scale application of bacterial decolorization.

Several fungi are capable of mineralizing pollutant compounds through their highly oxidative and non-specific ligninolytic enzymes, which are also responsible for the decolorization and degradation of many different dyes (Dos Santos et al., 2004). Recently, there is a growing interest in studying the brown rot fungi; Aspergillus niger, for the decolorization and degradation of many different dyes because their biomass can be used as an adsorbent and serve as a part of a technical solution in water pollution control ( $\mathrm{Fu}$ and Viraraghavan, 2000 and Srividhya et al., 2012). The present study aimed at using a newly screened, Aspergillus niger, a brown rot fungus, isolated from effluents of textile industry for decolorization of two azo-based synthetic dyes; Remazol blue and Remazol red. Various conditions required for decolorization have been optimized.

\section{MATERIALS AND METHODES}

Sampling: Effluent samples were collected from textile factory in ElBaragil, Giza, Egypt. Samples were collected in sterile air tight bottles with filtering through the ordinary filter paper to remove large suspended particles. Standard procedures were followed during sampling and samples were transported to the laboratory and stored at $4{ }^{\circ} \mathrm{C}$.

Media and chemicals: Two textile dyes, Remazol blue and Remazol red (kindly provided from Giza Spinning \& Weaving, El- Baragil) were used for the decolorization in the present investigation. All media components and 
chemicals used in the present study were of analytical grade. The chemical structure of Remazol red is shown in figure-1. The structure of the Remazol blue is not published.

Physiochemical analysis of effluents: Color, smell, temperature and $\mathrm{pH}$ of the various wastewater samples were recorded on the spot. Samples collected from the discharge sites were filtered through Whatman no.1 filter paper and their chemical oxygen demand (COD), biological oxygen demand (BOD), total suspended solids (TSS) and total dissolved solids (TDS) were determined using standard procedures according to (APHA, 2012).

Determination of absorption maxima ( $\lambda \max )$ of Remazol blue and Remazol red: The absorption maximum was determined by using a spectrophotometer. Optical density of dye solution in water was observed at different wavelength between visible regions $(340-700 \mathrm{~nm})$. The wavelength where, the dyes showed maximum absorbance is taken as absorption maximum of the dye; for Remazol blue and for Remazol red it was observed $600 \mathrm{~nm}$ and $530 \mathrm{~nm}$ respectively. .

Isolation and Identification of dye decolorizing fungi: Fungal strains native to the sampled area were isolated on Sabouraud Dextrose Agar (SDA) using a dilution plate technique (Harley and Prescott, 1993). The following composition of a medium was used (Peptone, $10 \mathrm{~g} / \mathrm{l}$; Dextrose, 40g/l; Agar, $12 \mathrm{~g} / \mathrm{l})$. The isolated fungal species were identified by Lactophenol cotton blue staining and microscopic analysis. Strains were preserved on SDA slants at $4^{\circ} \mathrm{C}$ in a refrigerator and were served as stock cultures. 
Dye decolorization experiment: From 6-day-old fungal culture on SDA, three mycelia disks (each $8 \mathrm{~mm}$ diameter) were cut from actively growing regions and inoculated to Erlenmeyer flasks containing $50 \mathrm{ml}$ of Sabouraud liquid medium (SLM) (Pancreatic digest of casein, Peptic digest of fresh meat, Glucose. pH5.7) amended with $100 \mathrm{mg} / \mathrm{l}$ experimental dye. Incubation was carried out at $30{ }^{\circ} \mathrm{C}$ in static condition for 5days, the culture broth was filtered then the filtrate was centrifuged at $10,000 \mathrm{rpm}$ for $15 \mathrm{~min}$. Absorbance of the supernatant was recorded at the corresponding $\lambda \max (600$ $\mathrm{nm})$ for Remazol blue and $\lambda \max (530 \mathrm{~nm})$ for Remazol red. The decolorization activity in terms of $(\%)$ decolorization was calculated from standard curve of the dye according to the formula given by Olukanni et al., (2006):

$$
\text { Decolorization } \%=\frac{\text { Ao-At }}{\text { Ao }} \times 100
$$

Where, Ao is initial absorbance of sample and Atis the absorbance at different time intervals.

Optimization: Decolorization of Remazol blue and Remazol red by selected fungal isolate was optimized with respect to different factors including:

- Time course $(2,4,6,8$ and 10 days $)$

- Temperature $\left(27,30,37,40\right.$ and $\left.45^{\circ} \mathrm{C}\right)$

- $\mathrm{pH}(3,4,5,6,7$ and 8$)$

- Dye concentrations (100, 200, 300,400,500 and 1000mg/ L)

Carbon sources (10 g/ L): (dextrose, sucrose and starch) 
- Nitrogen sources (2 g/ L): peptone, ammonium chloride and ammonium sulfate) using the experimental procedures as same as those for dye decolorization assay.

Statistical analysis: Data were analyzed using the mean of triplicates \pm standard deviation (SD).

\section{RESULTS AND DISCUSSION}

Physiochemical characterization of the textile effluent: The physiochemical analysis of sampled textile effluent helped us to measure the pollution level. Thus, the physiochemical parameters for effluents were conducted and examined (Table-1).

Table (1): Physiochemical characterization of effluents

\begin{tabular}{|c|c|c|}
\hline Parameter & Unit & Effluent \\
\hline \hline Color & - & max570nm) $(\lambda$ dark blue \\
\hline Smell & - & Pungent \\
\hline Temperature & ${ }^{\circ} \mathrm{C}$ & 39.8 \\
\hline $\mathrm{pH}$ & - & 8.7 \\
\hline BOD & $\mathrm{mg} / \mathrm{L}$ & 676 \\
\hline COD & $\mathrm{mg} / \mathrm{L}$ & 2360 \\
\hline TSS & $\mathrm{mg} / \mathrm{L}$ & 144 \\
\hline TDS & $\mathrm{mg} / \mathrm{L}$ & 2500 \\
\hline
\end{tabular}

Effluents color is dark blue due to the mixture of various dyes and chemicals used in the dyeing process (Devi and Kaushik, 2005). The pH of the effluent alters the physiochemical properties of water which in turn adversely affects the biodiversity. High $\mathrm{pH}$ is mainly due to the use of carbonate, bicarbonate andNaOH during bleaching process in the textile (Wood and Kellogg, 1988). Soil permeability gets affected, which results in 
polluting the underground resources of water (Buckley, 1992). Elevated temperature tends to decrease the solubility of gases in water, which is ultimately expressed as high BOD/COD. High TSS and TDS values reduce the light penetration into the water and ultimately decreases the photosynthesis in aquatic flora. This cause reduction in dissolved oxygen level of water bodies, which results for extremely low purification of wastewater by microorganism (Namdhariet al., 2012).

Isolation and Identification of dye decolorizing fungi: The three fungal strains were identified as Aspegillus niger, Aspergillus famigatus and Aspergillus terreus. The occurrence of fungi in the polluted water depends on the availability of nutrient, oxygen, biological, physical and chemical characteristics of the pollutants .Aspergillus species are well adapted to textile waste water and are frequently isolated from effluents and dye contaminated soils (Devi and Kaushik, 2005 and Ponraj et al., 2011).

\section{Optimization of culture conditions for maximum dye decolorization}

Effect of time course on decolorization: Decolorization for Remazol blue and Remazol red was studied (Fig. 2), The two dyes were decolorized after 4 days of incubation at $30{ }^{\circ} \mathrm{C}$. The dyes wereabsorbed by the biomass and the visual observation of decolorization of the dyes was from the 3rd-6th day of incubation. The color of the biomass of fungus changed to the color of the tested dye. The color on the biomass was reduced gradually from the 6th until 10th day of incubation. Bergsten-Torralba et al. (2009) and Yu and Wen (2005) reported that the decolorization of dyes by yeast and fungi can be due to adsorption of the dye to microbial cells or to biodegradation. The present experiments demonstrated the efficiency of A. niger to decolorize the two 
kinds of dyes, with differences in the decolorization ability. The mechanism of decolorization may be due to biosorbtion, which is dependent on functional groups in the dye molecule and in fungal biomass, which may also play role in the biosorption of dye (Raju et al., 2007; Fu and Viraraghavan, 2002).

Effect of temperature on dye decolorization: The extent of dye decolorization increased with an increase in temperature from 25 to $30{ }^{\circ} \mathrm{C}$, and highest degree of decolorization was reported at $30^{\circ} \mathrm{C}$ (Fig. 3).

The maximum decolorization at this temperature may be due to high rate of respiration, substrate metabolism and production of dye degrading enzymes. However, the decolorization extent found to be decreased as the incubation temperature was set beyond $30{ }^{\circ} \mathrm{C}$. This might have occurred due to adverse effect of high temperature on the fungal growth and enzymatic activities (Cetin and Donme, 2006).

Effect of initial pHon decolorization: Decolorization maxima were recorded at $\mathrm{pH}$ 4.0. This was supported by the fact that slightlyacidic environment was preferable for metabolic activity of A.niger, hence the greatest extent of decolorization which tends to fall sharply below and beyond pH4.0 (Fig. 4).

This may be due to the electrostatic attraction between negatively charged dye anions and positively charged cell surface at lower $\mathrm{pH}$ values (Mahony et al., 2002).

Effect of dye concentrations on dye decolorization: For industrial applications, the tolerance of microorganism to higher concentrations of the dyes is an important factor since the dye concentration in a typical lindustrial effluent can vary between 60 and 250mg/ L (Pierce, 1994). The effect of 
initial dye concentrations on decolorization of Remazole blue is shown in Fig. (5), where a decrease in dye removal was observed with increasing initial dye concentrations. Kumar et al. (2009) tested various initial concentrations of dye ranging from 25 to $300 \mathrm{ppm}$ and found that percentage removal of dye decreased with an increase in dye concentration. A slower decolorization rate was attributed to higher molecular weight, structural complexity and the presence of inhibitory functional groups like $-\mathrm{NO} 2$ and $-\mathrm{SO} 3 \mathrm{Na}$ in the dyes (Hu and $\mathrm{Wu}, 2001$ ).

Effect of carbon sources on dye decolorizationAmong the carbon sources tested, maximum decolorization was recorded with dextrose (Fig. 6), however, starch is more cheaper makes it a better economic choice. Jin et al. (2007) reported that improved decolorization was observed with potato starch and sucrose during the decolorization of a mixture of reactive dyes. Readily usable carbon sources are mandatory for fungal growth, and subsequent production of secondary metabolites and extracellular enzymes for biodegradation and/or adsorption (Khelifi et al., 2009).

Effect of nitrogen sources on dye decolorization: A.niger exhibited high growth and decolorization percentage of Remazol blue and Remazol red with all utilized nitrogen sources. However, organic nitrogen source was found to be less satisfactory in decolorization process than the inorganic ones. Use of ammonium sulfate resulted in the highest decolorization among the nitrogen sources tested (Fig. 7). The possible explanation behind ammonium salt assimilation by fungi is that, by directly using ammonia, fungal cell would likely to convert nitrogen into the glutamate and glutamine amino acids that 
serve as nitrogen donors for all other nitrogen-containing compounds in the cell (Eelko et al., 2000).

\section{CONCLUSION}

To comply with the strict environmental legislation, it is necessary to explore innovative environmental technologies for the treatment of colored dying effluents. The present study focuses on the isolation, identification of indigenous fungus A.niger for decolorization of a textile dyes Remazol blue and Remazol red. Results showed that A.niger has the ability to remediate the dyes from the effluent and decolorization of the tested dyes can be improved by providing appropriate culture conditions and maintaining microbial inoculants at active physiological state. Further, it can be suggested that dye contaminated sites can potentially be reclaimed by a low cost bioremediation process with native fungal species isolated from the dye disposal sites.

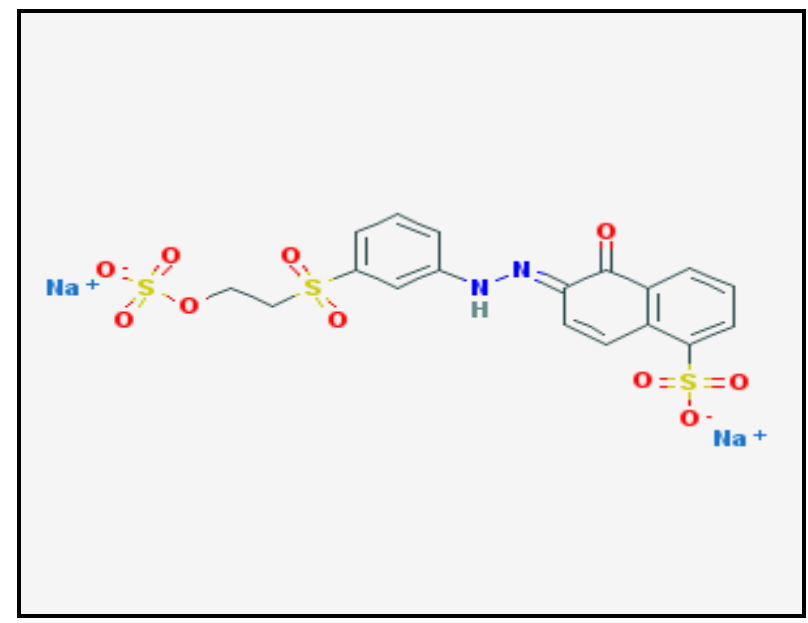


J. Environ. Sci.

Institute of Environmental Studies and Research - Ain Shams University

Fig. (1): Chemical structure of RemazolRed(IUPAC name:disodium;(6E)-5oxo-6-[[3-(2-sulfonatooxyethylsulfonyl)phenyl] hydrazinylidene] naphthalene-1-sulfonate)

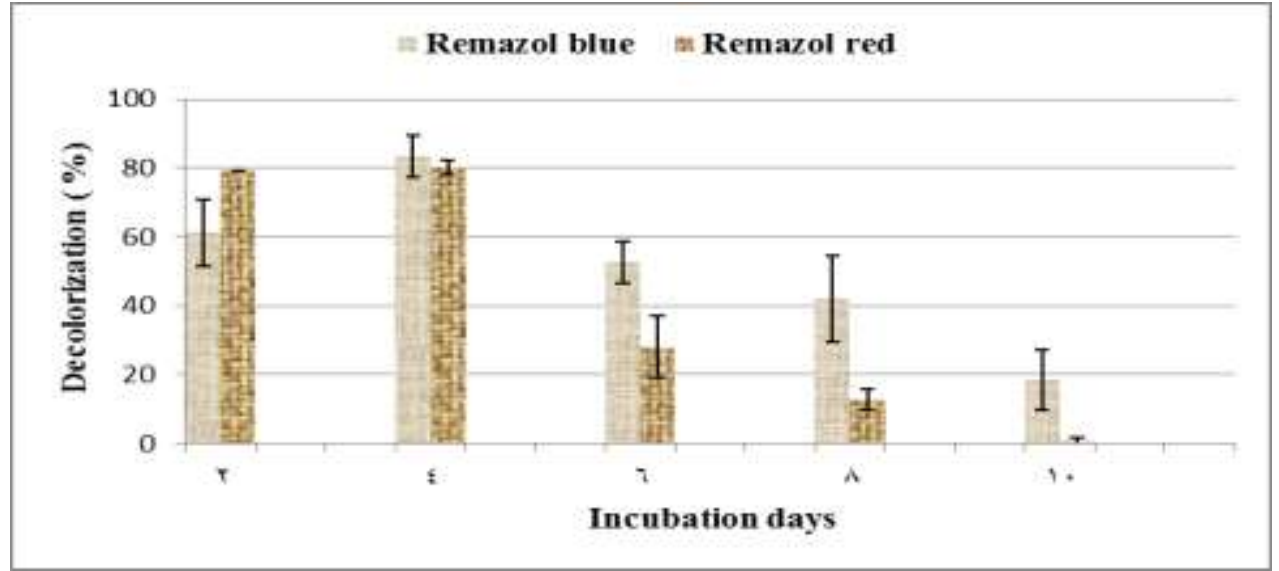

Fig. (2): Effect of time course on decolorizationof Remazol blue and Remazol red by A.niger

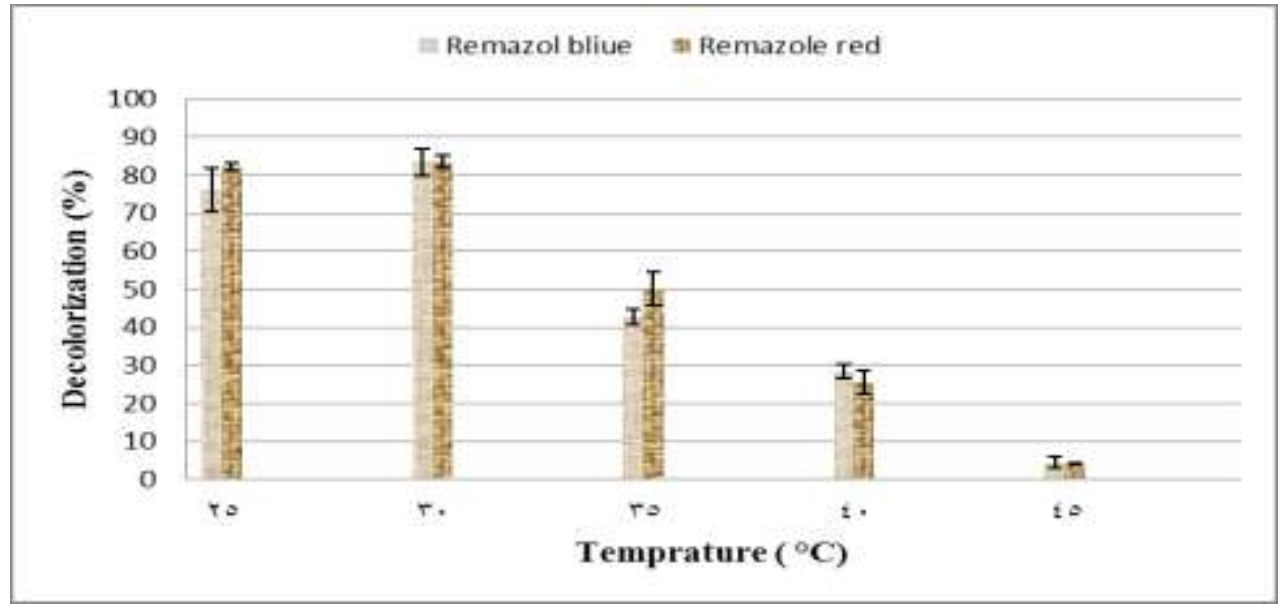

Fig. (3): Effect of temperature on decolorization of Remazol blue and Remazol red by A.niger 


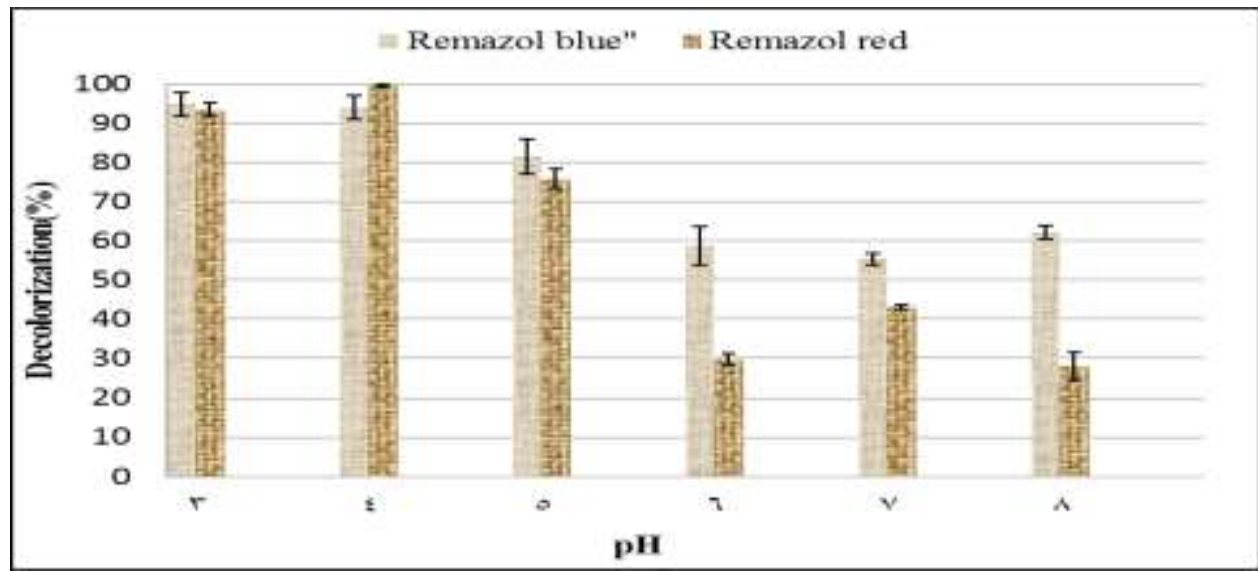

Fig. (4): Effect of $\mathrm{pH}$ on decolorization of Remazol blue and Remazol red by A.niger

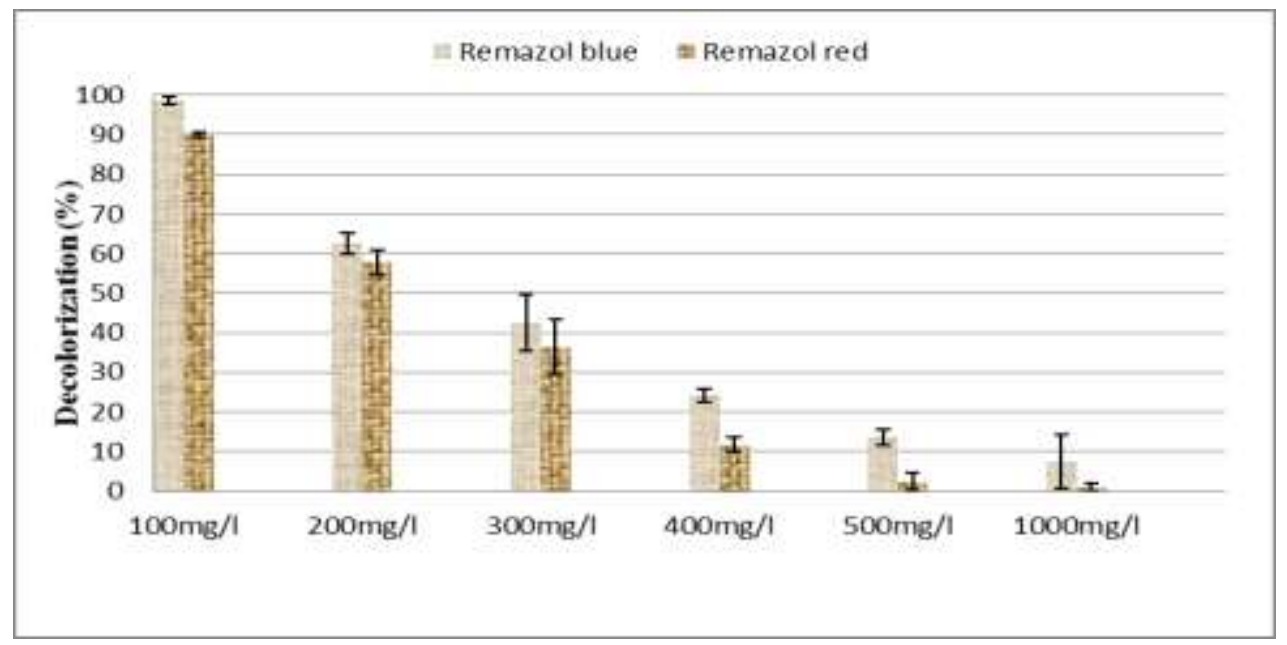

Fig. (5): Effect of different dye concentrations on decolorization of Remazol blue and Remazol red by A.niger 
J. Environ. Sci.

Institute of Environmental Studies and Research - Ain Shams University

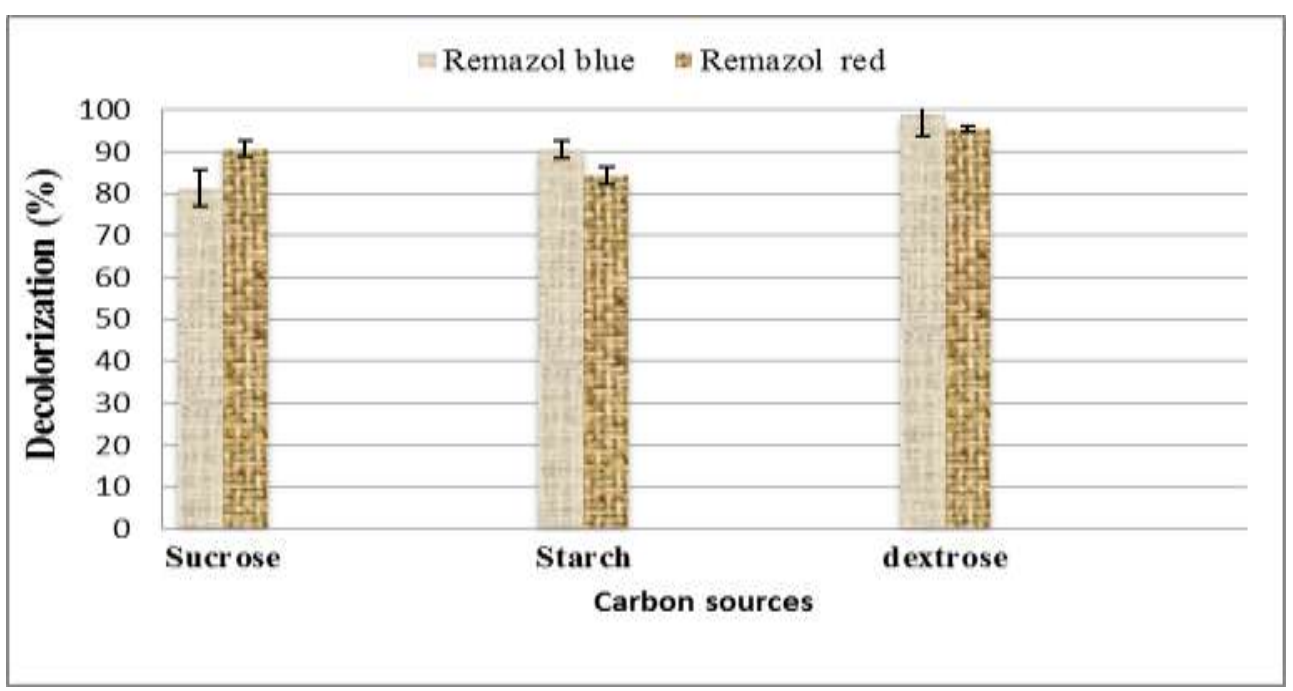

Fig. (6): Effect of different carbon sources on decolorization of Remazol blue and Remazol red by A.niger

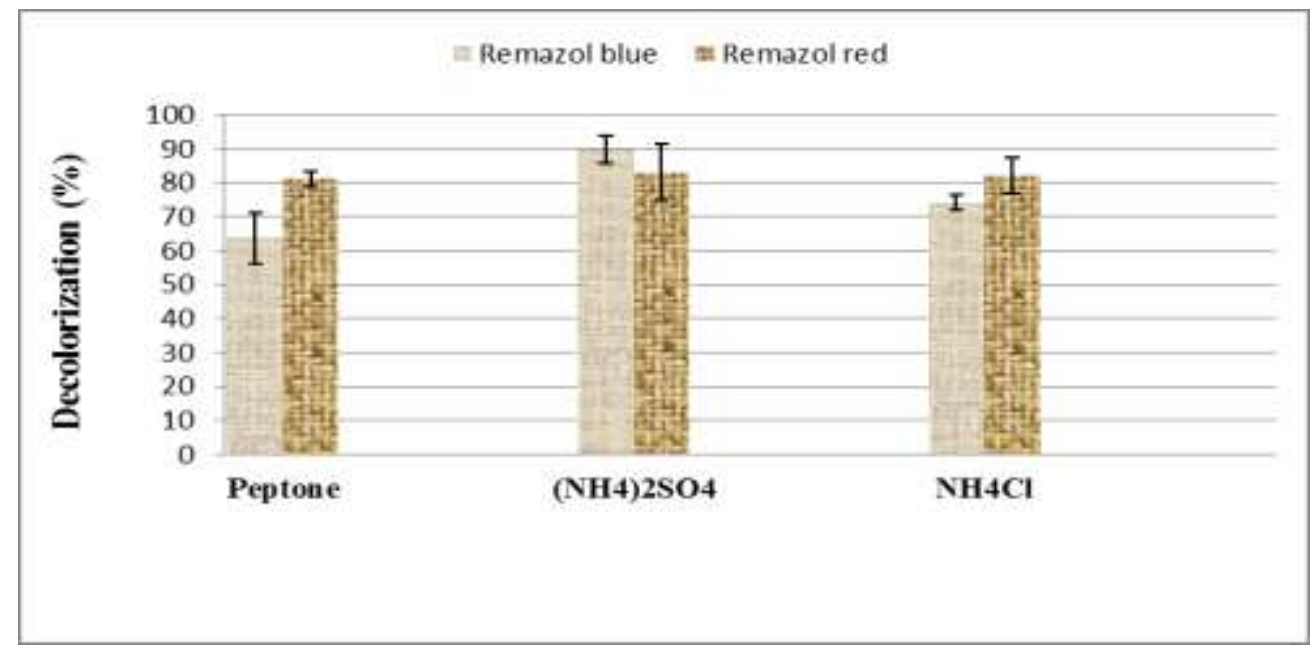

Fig. (7): Effect of different nitrogen sources on decolorizationof Remazol blue and Remazol red by A.niger 


\section{REFRENCES}

APHA (2012): Standard Method for the Examination of Water and Wastewater, 22th ed. American Public Health Association,2120 E, Washington, DC, USA.

Balapure, K.; Bhatt, N. and Madamwar, D.(2014): Mineralization of reactive azo dyes present in simulated textile waste water using down flow microaerophilic fixed film bioreactor. Bioresour. Technol, 175C: $1-7$.

Bergsten-Torralba, L. R.; Nishikawa,M. M.; Baptista, D. F.; Magalhaes, D. P. and da Silva, M. (2009): Decolorization of different textile dyes by Penicillium simplicissimum and toxicity evaluation after fungal treatment. Braz. J. Microbiol., 40: 808-817.

Buckley C. A. (1992): Membrane technology for the treatment of dye house effluents, Water Sci. Techno., 25 (10): 203-209.

Cetin, D. and Donmez, G. (2006): Decolorization of reactive dyes by mixed cultures isolated from textile effluent under anaerobic condition. Enzyme Microb Technol., 38:926-930.

Chung, K. T. and Stevens,S. E. (1993): Degradation azo dyes by environmental microorganisms and helminths. Environ. Toxicol. Chem., 12: 2121-2132.

Davies, L.C.; Pedro, I. S.; Novais, J. M. and Martins-Dias, S.(2006): Aerobic degradation of acid orange 7 in a vertical-flow constructed wetland. Water Res. 40: 2055-2063.

De Miranda, R. M.; Gomes, E.; Pereira Jr., N.; Marin-Morales, M. A.; Machado, K. M. and Gusmão, N. B. (2013): Biotreatment of textile effluent in static bioreactor by Curvularialunata URM 6179 and Phanerochaete chrysosporium URM 6181.Bioresour. Technol., 142: 361-367.

Devi, M. and Kaushik, B. D. (2005): Decolorization of textile dyes and dye effluent by Aspergillus Spp., Indian J. Microbiol., 45: 41-44.

Dos Santos, A. B.; Cervantes, F. J. and Van Lier, J. B. (2007): Review paper on current technologies for decolourisation of textile wastewaters: 
perspectives for anaerobic biotechnology. Bioresour. Technol. 98: 2369-2385.

Dos Santos, A. Z.; NetoJ. M.; Tavares C. R. G. and da Costa S. M. G. (2004): Screening of filamentous fungi for the decolorization of a commercial reactive dye. J. Basic Microbiol., 44: 288-295.

Eelko, G. S.; Natal, A. W. and Theo, V .C. (2000): The role of ammonia metabolism in nitrogen catabolite repression in Saccharomyces cerevisiae. FEMS Microbiol Rev., 24:67-83.

$\mathrm{Fu}, \mathrm{Y}$. and Viraraghavan, T. (2000): Removal of a dye from an aqueous solution by the fungus Aspergillus niger. Water Qual. Res. J. Can., 35: 95-111.

$\mathrm{Fu}, \mathrm{Y}$. and Viraraghavan, T. (2002): Dye biosorption sites in Aspergillus niger. Biores. Technol., 82: 139-145.

Harley, J.P. and Prescott, L. M. (1993): Basic laboratory and culture techniques. In: Laboratory excercises in Microbiology. 2nd Ed. W.C. Brown Publishers, Dubuque: 14-46.

Hu, T .L.and Wu, S. C. (2001): Assessment of the effect of azo dye Rp2B on the growth of nitrogen fixing cyanobacteriumAnabena $\mathrm{sp}$. BioresourTechnol., 77(1):93-95.

Jin, X. C.; Liu, G. Q; Xu, Z .H. and Tao, W. Y. (2007): Decolorization of a dye industry effluent by Aspergillus fumigatus XC6. Appl Microbiol Biotechnol., 74(1):239-243.

Khelifi, E ; Ayed L.; Bouallagui H.; Touhami Y. and Hamdi, M. (2009): Effect of nitrogen and carbon sources on indigo and Congo red decolorization by Aspergillusalliaceus strain 121C. J Hazard Mater, 163:1056-1062.

Kumar, K.; Dastidar M. G.; Sreekrishnan T. R. (2009): Effect of process parameters on aerobic decolourization of reactive azo dye using mixed culture. World AcadSciEngTechnol., 58:962-965.

Mahony, T. O.; Guibal, E.; Tobin, J. (2002): Reactive dye biosorption by Rhizopusarrhizus biomass. Enzyme Microb Technol., 31(4):456463. 
Namdhari, B.S.; Rohilla S. K.; Salar, R. K; Gahlawat S. K. ;Bansal, P. and Saran A. K.: Decolorization of Reactive Blue MR, using Aspergillusspecies Isolated from Textile Waste Water ISCA Journal of Biological Sciences , 1(1): 24-29, (2012).

Olukanni, O. D.; Osuntoki, A. A. and Gbenle, G.O. (2006): Textile effluent biodegradation potentials of textile adapted and non-adapted bacteria, African J. Biotechnol., 5:1980-1984.

Ong, S.; Uchiyama, K.; Inadama, D.; Ishida, Y. and Yamagiwa, K.(2010): Treatment of azo dye Acid Orange 7 containing wastewater using up-flow constructed wetland with and without supplementary aeration. Bioresour. Technol. 101: 9049-9057.

Pandey, A.; Singh, P. and Iyengar, L. (2007): Bacterial decolorization and degradation of azo dyes. Int. Biodeterior. Biodegrad. 59: 73-84.

Pearce, C. I.; Lloyd, J. R. and Guthrie, J. T. (2003): The removal of color from textile wastewater using whole bacterial cells: a review. Dyes Pigm., 58: 179-196.

Pierce, J. (1994): Colour in textile effluents - the origins of the problem. J Soc Dyers Color 110:131-133.

Ponraj, M.;Gokila, K. and Vasudeo, Z.(2011): Bacterial decolorization of textile dye- Orange 3R.International J. Adv. Biotechnol. Res., 2(1), 168-177.

Raju, N. S.; Venkataramana, G. V.; Girish S. T.; Raghavendra,V. B. and Shivashankar, P. (2007): Isolation and evaluation of indigenous soil fungi for decolourization of textile dyes. J. Applied Sci., 7: 298-301.

Sarayu, K. and Sandhya, S. (2010): Aerobic biodegradation pathway for remazol orange by Pseudomonas aeruginosa. Appl. Biochem. Biotechnol., 160: 1241-1253.

Saroj, S.; Kumar, K.; Pareek, N.; Prasad, R. and Singh, R. P. (2014): Biodegradation of azo dyes acid red 183, direct blue 15 and direct red 75 by the isolate Penicilliumoxalicum SAR-3. Chemosphere, 107: $240-248$. 
Singh, P.; Sanghi, R.; Pandey, A. andIyengar, L. (2007): Decolorization and partial degradation of monoazo dyes in sequential fixed-film anaerobic batch reactor(SFABR). Bioresour. Technol, 98: 20532056.

Srividhya, R.; Mary, A. L.; Mukesh G. and Rangabhashiyam, S.(2012): Decolorization study of synthetic optilan red dye by Aspergillus niger. Int. J. Recent Scient. Res., 3: 301-303.

Tauber, M. M.; Gübitz, G.M. and Rehorek, A. (2008): Degradation of azo dyes by oxidative processes-laccase and ultrasound treatment. Bioresour. Technol. 99: 4213-4220.

Wood, W.A. and Kellogg S. T.(1988): Biomass, cellulose and hemicelluloses, Methods Enzymol., 160: 632-634.

Yu, Z. and Wen, X. (2005): Screening and identification of yeasts for decolorizing synthetic dyes in industrial wastewater. Int. Biodeterior. Biodegrad., 56: 109-114.

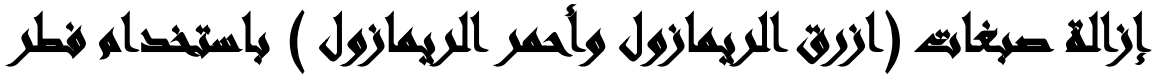

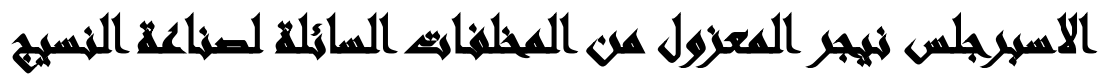

[r]

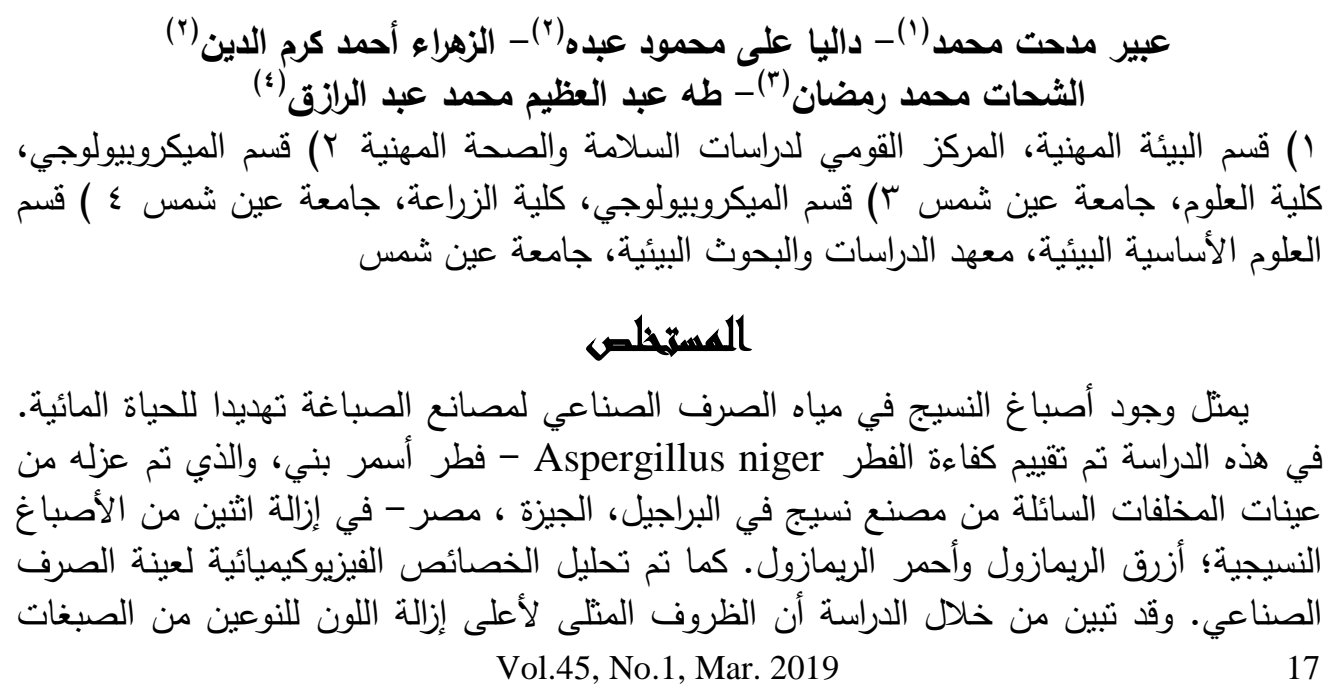




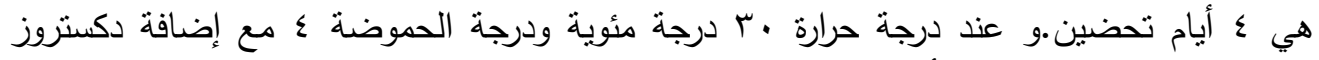

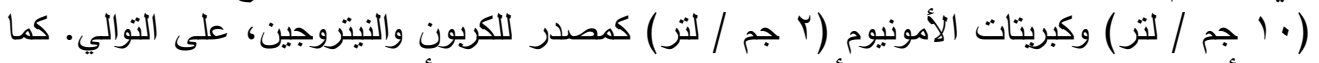

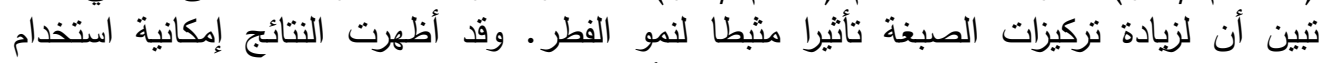

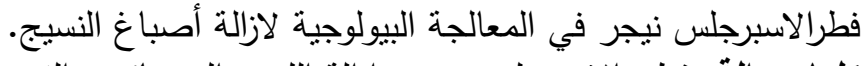
كلمات دالة: فطر الاسبرجلس نيجر ، إزالة اللون، الخصائية لازلة الصباغ الفيزيوكيميائية، أصباغ النسيج. 